\title{
Epigenetic inactivation of SLIT3 and SLITI genes in human cancers
}

\author{
RE Dickinson', A Dallol', I Bieche², D Krex ${ }^{3}$, D Morton ${ }^{4}$, ER Maher ${ }^{1,5}$ and F Latif ${ }^{* 1,5}$ \\ 'Section of Medical and Molecular Genetics, Division of Reproductive and Child Health, Institute of Biomedical Research, University of Birmingham, \\ Birmingham B 5 2TT, UK; ${ }^{2}$ Laboratoire d'Oncogénétique - INSERM E00 17, Centre René Huguenin, 35, rue Dailly, F-922IO St-Cloud, France; \\ ${ }^{3}$ Department of Neurosurgery, Universitätsklinikum Carl Gustav Carus, Technische Universität Dresden, Fetscherstraße 74, 01307 Dresden, Germany; \\ ${ }^{4}$ Department of Surgery, University of Birmingham, Birmingham B/5 2TT, UK; ${ }^{5}$ Cancer Research UK Renal Molecular Oncology Research Group, \\ University of Birmingham, Birmingham BI 5 2TG, UK
}

In Drosophila, the Slit gene product, a secreted glycoprotein, acts as a midline repellent to guide axonal development during embryogenesis. Three human Slit gene orthologues have been characterised and recently we reported frequent promoter region hypermethylation and transcriptional silencing of SLIT2 in lung, breast, colorectal and glioma cell lines and primary tumours. Furthermore, re-expression of SLIT2 inhibited the growth of cancer cell lines so that SLIT2 appears to function as a novel tumour suppressor gene (TSG). We analysed the expression of SLIT3 (5q35-34) and SLITI (I q23.3-q24) genes in 20 normal human tissues. Similar to SLIT2 expression profile, SLIT3 is expressed strongly in many tissues, while SLITI expression is neuronal specific. We analysed the $5^{\prime}$ CPG island of SLIT3 and SLITI genes in tumour cell lines and primary tumours for hypermethylation. SLIT3 was found to be methylated in 12 out of 29 (4I\%) of breast, one out of 15 (6.7\%) lung, two out of six (33\%) colorectal and in two out of (29\%) glioma tumour cell lines. In tumour cell lines, silenced SLIT3 associated with hypermethylation and was re-expressed after treatment with 5-aza-2'-deoxycytidine. In primary tumours, SLIT3 was methylated in 16\% of primary breast tumours, 35\% of gliomas and 38\% of colorectal tumours. Direct sequencing of bisulphite-modified DNA from methylated tumour cell lines and primary tumours demonstrated that majority of the CPG sites analysed were heavily methylated. Thus, both SLIT2 and SLIT3 are frequently methylated in gliomas and colorectal cancers, but the frequency of SLIT3 methylation in lung and breast cancer is significantly less than that for SLIT2. We also demonstrated SLITI promoter region hypermethylation in glioma tumour lines (five out of six; 83\%), the methylation frequency in glioma tumours was much lower (two out of 20; 10\%). Hence, evidence is accumulating for the involvement of members of the guidance cues molecules and their receptors in tumour development.

British Journal of Cancer (2004) 91, 207I-2078. doi:I0.1038/sj.bjc.6602222 www.bjcancer.com

Published online 9 November 2004

(c) 2004 Cancer Research UK

Keywords: SLITI; SLIT3; methylation; tumours

Epigenetic inactivation of tumour suppressor genes (TSGs) by promoter region $\mathrm{CpG}$ island hypermethylation is now well documented and several TSGs have been demonstrated to be inactivated by this mechanism (reviewed in Jones and Baylin, 2002; Herman and Baylin, 2003). In more recent years, a novel class of TSGs has been identified where epigenetic inactivation plays the predominant role, while somatic mutations are rare. This class of genes is exemplified by the 3p21.3 TSG, Ras association domain family 1A gene (RASSF1A) (Dammann et al, 2000; Lerman and Minna, 2000; Agathanggelou et al, 2001; Burbee et al, 2001). The $\mathrm{CpG}$ island in the promoter region of isoform $\mathrm{A}$ is frequently and heavily methylated in many types of cancers, including lung, breast, kidney, NPC, gastric, bladder, neuroblastoma, testicular, etc. (reviewed in Pfeifer et al, 2002; Dammann et al, 2003), while somatic inactivating mutations are absent or rare.

*Correspondence: Dr F Latif, Section of Medical and Molecular Genetics, Division of Reproductive and Child Health, University of Birmingham, Birmingham BI5 2TT, UK; E-mail: flatifhgmp.mrc.ac.uk

Received 25 May 2004; revised 19 August 2004; accepted 21 September 2004; published online 9 November 2004
SLITs, ROBOs and Semaphorins belong to families of proteins that play important roles in axon guidance and cell migration in Drosophila and vertebrates (reviewed in Brose and TessierLavigne, 2000; Wong et al, 2002). These proteins are widely expressed in mammalian tissues and the expression is not confined to neurons. Hence, they may have other yet unidentified roles. Slits are secreted proteins that are ligands for the Robo receptors (Brose et al, 1999; Kidd et al, 1999; Li et al, 1999). Recently, Slit was shown to inhibit leucocyte chemotaxis, this inhibition appears to be mediated by Robo (Wu et al, 2001). In mammals, four Robo genes have so far been identified, Robo1, Robo2, Rig-1 (Robo3) and magic Robo (Robo4) (Kidd et al, 1998; Sundaresan et al, 1998; Yuan et al, 1999; Huminiecki et al, 2002). In humans, ROBO1 is located at 3 p12 within a critical region of overlapping homozygous deletions in lung and breast cancers (Sundaresan et al, 1998). This region also demonstrated a high frequency of allele loss in lung, kidney and breast cancers. Majority of mice with deletion of exon 2 of Robol die at birth because of delayed lung maturation, the surviving mice develop bronchial hyperplasia (Xian et al, 2001). In an earlier study, we demonstrated that there were no inactivating somatic mutations in $\mathrm{ROBO1}$ in lung and breast cancers, but a CpG island in the $5^{\prime}$ region of $R O B O 1$ was hypermethylated in breast and kidney tumours (Dallol et al, 2002b). We went on to analyse 
the ligand SLIT2 located at 4p15.2 for genetic/epigenetic inactivation in tumours. The $4 \mathrm{p} 15.2$ region shows frequent allele loss in lung, breast, colorectal and head and neck cancers. SLIT2 promoter region $\mathrm{CpG}$ island was found to be frequently hypermethylated in lung, breast, colorectal and glioma tumours, while somatic mutations were not found (Dallol et al, 2002a, 2003a, b). Furthermore, we demonstrated in vitro growth suppression when SLIT2 was expressed in tumour cell lines that had no endogenous SLIT2 expression due to methylation. A recent paper demonstrated that in mice slit2 homozygous deficiency was lethal (Plump et al, 2002).

In this report, we analysed the methylation status of $5^{\prime} \mathrm{CpGs}$ islands for the remaining SLIT gene family members (SLIT3 and SLIT1) in human cancers.

\section{MATERIALS AND METHODS}

\section{Patients and samples}

A total of 60 glioma samples, plus seven glioma tumour cell lines (T17, U87-MG, A172, U343, HS683, U373, H4) were analysed for methylation. Among the glioma samples, 40 were classified as gliomblastoma multiforme. The remaining gliomas were collected randomly and consisted of all grades. In addition, 32 colorectal cancer samples and their matching histologically normal mucosa, six colorectal tumour cell lines (SW48, HCT116, LS411, LS174T, DLD1, LoVo), 15 lung tumor cell lines, 32 invasive ductal breast carcinoma plus 29 breast tumour cell lines were also analysed for methylation. These have been described previously (Dallol et al, 2002a, 2003a, b)

\section{Bisulphite modification and methylation analysis}

Bisulphite DNA sequencing was performed as described previously (Agathanggelou et al, 2001). Briefly, $0.5-1.0 \mu \mathrm{g}$ of genomic DNA was denatured in $0.3 \mathrm{M} \mathrm{NaOH}$ for $15 \mathrm{~min}$ at $37^{\circ} \mathrm{C}$. Unmethylated cytosine residues were then sulphonated by incubation in $3.12 \mathrm{M}$ sodium bisulphite ( $\mathrm{pH}$ 5.0) (Sigma, Dorset, UK) and $5 \mathrm{~mm}$ hydroquinone (Sigma) in a thermocycler (Hybaid) for $15 \mathrm{~s}$ at $99^{\circ} \mathrm{C}$ and $15 \mathrm{~min}$ at $50^{\circ} \mathrm{C}$ for 20 cycles. Sulphonated DNA was then recovered using the Wizard DNA cleanup system (Promega, Southampton, UK) according to the manufacturers' instructions. The DNA was desulphonated by addition of $0.3 \mathrm{M} \mathrm{NaOH}$ for $10 \mathrm{~min}$ at room temperature. The converted DNA was then ethanol precipitated and resuspended in water.

Table I Expression and methylation primer sequences and PCR conditions

\begin{tabular}{|c|c|c|c|c|}
\hline Primer name & Primer sequence $\left(5^{\prime}\right.$ to $\left.3^{\prime}\right)$ & $\begin{array}{l}\text { Annealing temp. for } \\
\text { PCR ( } \mathrm{C})\end{array}$ & $\begin{array}{l}\mathrm{MgCl}_{2} \text { conc. } \\
(\mathrm{mM})\end{array}$ & $\begin{array}{l}\text { Predicted product } \\
\text { size (bp) }\end{array}$ \\
\hline $\begin{array}{l}\text { SLIT3 COBRA F } \\
\text { SLIT3 COBRA R } \\
\text { SLIT3 COBRA RN }\end{array}$ & $\begin{array}{l}\text { GGT-TAG-TTT-ATT-YGG-TYG-TTT-YGT-G TT-TTA-GT } \\
\text { TAC-CCA-CCC-RAA-AAC-CAT-AAT-ATA-CAA-AA } \\
\text { CCA-CTC-CTA-AAA-AAA-ACT-ACC-TCT-A }\end{array}$ & 55 & 1.5 & 394 \\
\hline $\begin{array}{l}\text { SLITI COBRA F } \\
\text { SLITI COBRA R } \\
\text { SLITI COBRA FN }\end{array}$ & $\begin{array}{l}\text { GTT-TAT-TT1-TI-TTT-YGT-AGT-AGT-TAG-TTG-GGA-GT } \\
\text { TAA-CAA-TCC-ACC-RTA-ATT-CCR-ATA-CAA-ATA-CAA-AAA } \\
\text { GGY-GAA-AYG-GTA-GAG-GAG-TYG-AGT-TTT-T }\end{array}$ & 57 & 1.5 & 370 \\
\hline $\begin{array}{l}\text { GAPDH expression } F \\
\text { GAPDH expression } R\end{array}$ & $\begin{array}{l}\text { TGA-AGT-TCG-GAG-TCA-ACG-GAT-TTG-GT } \\
\text { CAT-GTG-GGC-CAT-GAG-GTC-CAC-CAC }\end{array}$ & 60 & 1.5 & 982 \\
\hline $\begin{array}{l}\text { SLST3 expression F } \\
\text { SLIT3 expression R }\end{array}$ & $\begin{array}{l}\text { CAA-GTG-TGC-CGA-GGG-CTA-TGG-AG } \\
\text { ACG-GG C-TTA-GGA-ACA-CGC-GAG-G }\end{array}$ & 65 & 1.5 & 419 \\
\hline $\begin{array}{l}\text { SLIT I expression F } \\
\text { SLIT I expression R }\end{array}$ & $\begin{array}{l}\text { GTG-ACA-ACT-GCA-GTG-AGA-AC } \\
\text { GTA-CAG-CTC-AAC-TGC-AAT-GT }\end{array}$ & 55 & 1.5 & 422 \\
\hline
\end{tabular}

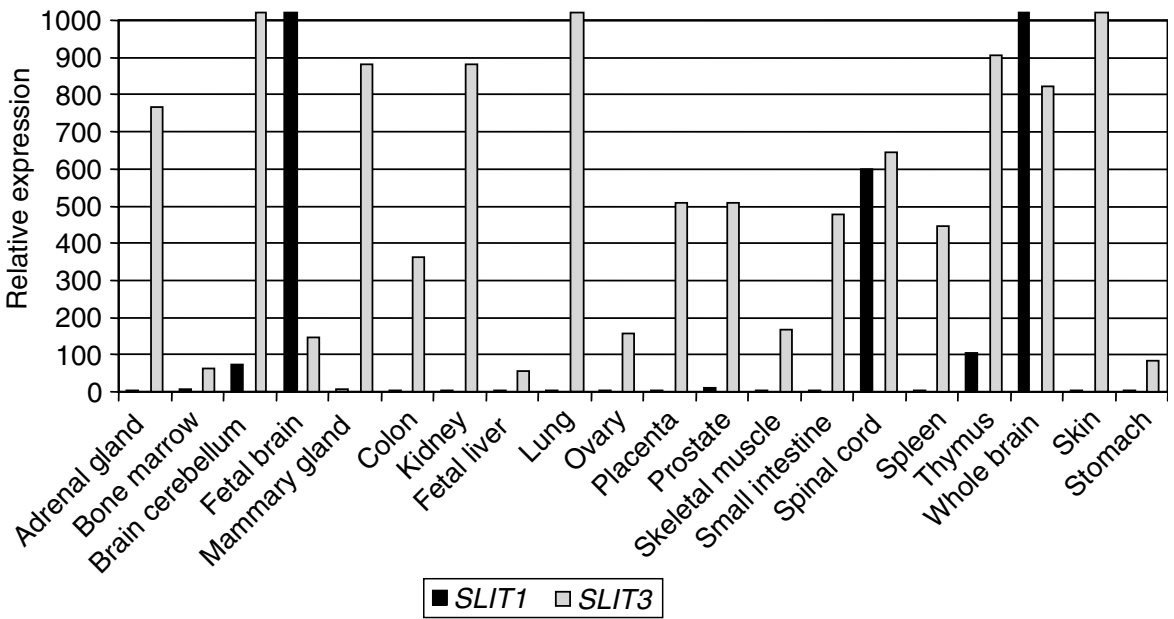

Figure I Quantitative real-time RT-PCR was used to measure SLITI and 3 expression levels in 20 normal human tissues. See Materials and Methods for real-time RT-PCR details. RPLPO gene transcript was used as the endogenous RNA control and each sample was normalised on the basis of its RPLPO content. 


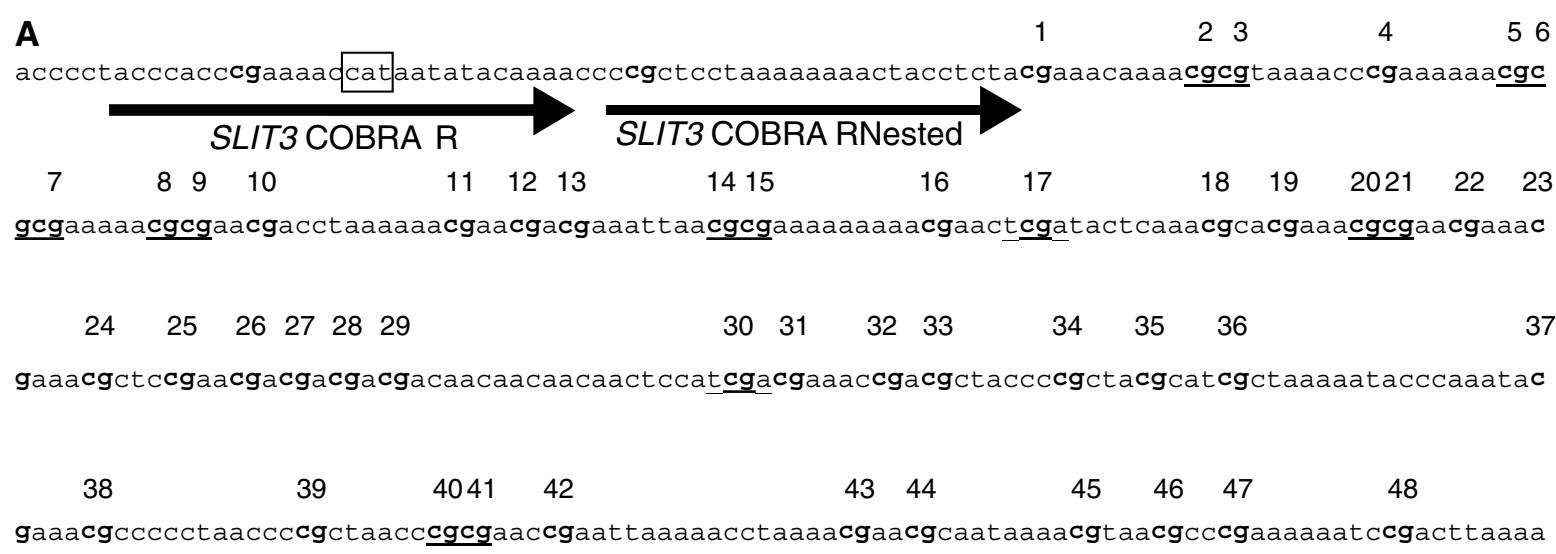

ctaaactaaaaacgcgacgactacgactaaaacacgaaacgaccgaataact

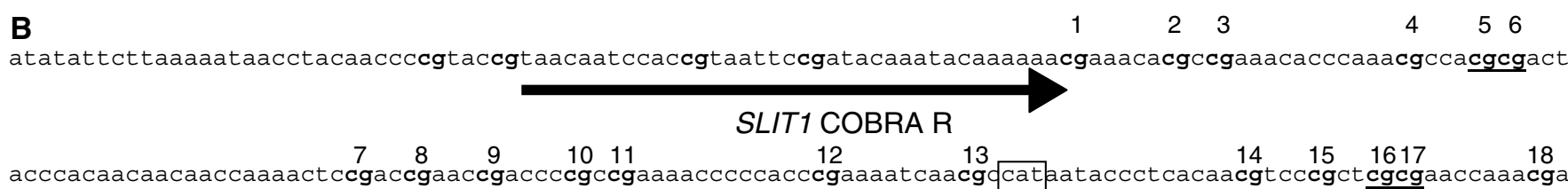

$\begin{array}{llllllllll}19 & 20 & 21 & 22 & 23 & 24 & 2526 & 272829 & 30 & 31\end{array}$

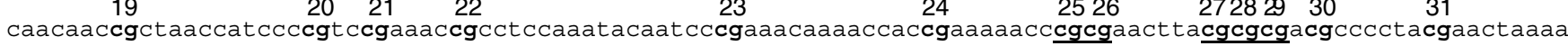

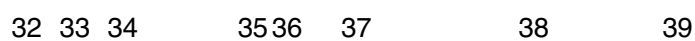
aacaccttactcctccaaacgacgacgcctatacgcgaacgaaaaaaaaacgccttaaacgaaaaaaactcgactcctctaccgtttcgccgcctacgtctccctct SLIT1 COBRA FNested

cctccctccaactcccaactaactactacgaaaaaaaaataaacaaaccccacgcgc

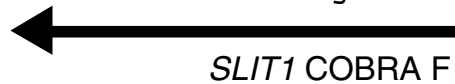

Figure 2 (A) Sequence of the reverse bisulphate-modified SLIT3 promoter region CpG island fragment. Arrows indicate the position of the primers for COBRA. CG dinucleotides within the amplification region are numbered I-52 and sequences underlined are BstUI and Taql sites used to detect methylation. The expected amplicon size from SLIT3 COBRA F to SLIT3 COBRA RNested is $394 \mathrm{bp}$. The box represents the transcriptional start site of SLIT3. (B) Sequence of the reverse bisulphate-modified SLITI promoter region CpG island fragment. Arrows indicate the position of the primers for COBRA. CG dinucleotides within the amplification region are numbered I-39 and sequences underlined are BstUI sites used to detect methylation. The expected amplicon size for SLITI FNested to SLITI R is $370 \mathrm{bp}$. The box represents the transcriptional start site of SLITI.

\section{Combined bisulphite restriction analysis (COBRA) and sequencing}

All reactions were performed on a thermocylcer (Hybaid) and with HotStar Taq Polymerase (Quiagen, West Sussex, UK). The promoter methylation status of SLIT3 and SLIT1 were determined using the COBRA method followed by sequencing to confirm methylation and ascertain the extent of methylation. The cycling conditions were as follows: initial denaturation for $10 \mathrm{~min}$ at $95^{\circ} \mathrm{C}$, followed by $25-35$ cycles of $1 \mathrm{~min}$ at $95^{\circ} \mathrm{C}, 1 \mathrm{~min}$ at annealing temperature and $2 \mathrm{~min}$ at $74^{\circ} \mathrm{C}$ with a final extension for $5 \mathrm{~min}$ at $74^{\circ} \mathrm{C}$ using the forward and reverse primers. The reaction volume of $20 \mu \mathrm{l}$ contained $40 \mathrm{ng}$ bisulphate-modified DNA, $1 \times$ PCR Buffer containing $1.5 \mathrm{mM} \mathrm{MgCl}_{2}$ (Quiagen), $0.2 \mathrm{M}$ dNTPs, $0.4 \mu \mathrm{M}$ each primer and $0.5 \mathrm{U}$ HotStar Taq (Qiagen). Then, $1 \mu \mathrm{l}$ of this reaction was used in a seminested PCR reaction $(50 \mu \mathrm{l})$ using forward and reverse nested primers in the case of SLIT3 and reverse and forward nested primers for SLIT1. The same PCR programme and concentration of reagents were used as before. The annealing temperature, $\mathrm{MgCl}_{2}$ concentration and sequences for the gene primers are listed in Table $1(\mathrm{Y}=\mathrm{C}$ or $\mathrm{T}$ and $\mathrm{R}=\mathrm{A}$ or $\mathrm{G})$. All PCR products were assayed for methylation by incubation with $B s t \mathrm{UI}$ at $60^{\circ} \mathrm{C}$ or $\operatorname{Taq}^{\alpha} \mathrm{I}$ at $65^{\circ} \mathrm{C}$ for $2 \mathrm{~h}$ before visualisation on a $2 \%$ agarose gel with added ethidium bromide. The $\mathrm{CpG}$ island methylation status for SLIT3 was determined by cloning PCR products into pGEM T-Easy vector (Promega - according to manufacturers' instructions). At least five clones from each PCR product were then prepared for sequencing. SLIT3 Colony PCR products were purified using the QIAquick PCR Purification Columns (Quiagen - according to manufacturers' instructions) and then reamplified using ABI BigDye Cycle Sequencing Kit (Perkin-Elmer, Warrington, UK) with the reverse nested primer (as shown in Figure 2A). The SLIT1 COBRA PCR products were purified and then 


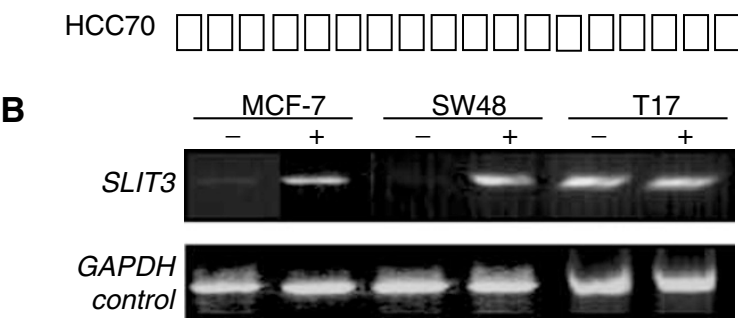

Figure 3 (A) SLIT3 CPG island COBRA PCR products were cloned and sequenced from breast (MCF7, HCC7I2, HCC 38 and HCC70) and colorectal (SW48) tumour cell lines. For each tumour cell line, several clones were sequenced and the methylation status for the first 30 CpGs is shown. White and black squares represent unmethylated and methylated CpGs, respectively. Partially filled squares represent partially methylated CpGs. (B) Expression of SLIT3 in methylated breast (MCF7) and colorectal (SW48) cell lines before and after treatment with the demethylating agent 5-aza-2'-deoxycytidine (5-aza $\mathrm{dC})$. Gene expression was restored by 5 -aza-dC $(+)$ in methylated cell lines that lacked SLIT3 expression. GAPDH and the unmethylated glioma cell line TI7 were used as positive controls to ensure RNA integrity and equal loading.

sequenced directly as described above, but with the reverse primer. The reactions were then analysed using an ABI Prism 377 DNA sequencer (Perkin-Elmer).

\section{Real-time RT-PCR}

The theoretical and practical aspects of real-time quantitative RT PCR using the ABI Prism 7700 Sequence Detection System (Perkin-Elmer) have been described in detail elsewhere (Dallol et al, 2002a). Briefly, total RNA was reverse transcribed before realtime PCR amplification. Quantitative values were obtained from the threshold cycle $\left(C_{\mathrm{t}}\right)$ number at which the increase in the signal associated with exponential growth of PCR products begins to be detected using the PE Biosystems analysis software, according to the manufacturers' manuals. The precise amount of total RNA added to each reaction mix and the quality was difficult to assess. We therefore also quantified transcripts of the gene RPLPO (also known as 36B4) encoding human acidic ribosomal phosphoprotein $\mathrm{PO}$ as the endogenous RNA control, and each sample was normalised on the basis of its RPLPO content. Results, expressed as $\mathrm{N}$-fold differences in target gene expression relative to the $R P L P O$ gene, termed 'Ntarget', were determined by the formula: Ntarget $=2^{\Delta \text { Ctsample }}$, where $\Delta C_{\mathrm{t}}$ value of the sample was determined by subtracting the $C_{\mathrm{t}}$ value of the target gene from the $C_{\mathrm{t}}$ value of the RPLPO gene. The nucleotide sequences of the primers used for PCR amplification were the following: SLIT1-U (5'-CTGGATGG CTTGAGGACCCTAAT- $\left.3^{\prime}\right)$ and SLIT1-L ( $5^{\prime}$-GCCCGTGAAGCTGTC GTTGT-3') with a SLIT1-specific product size of $72 \mathrm{bp}$, SLIT3-U $\left(5^{\prime}\right.$-GAATATGTCACCGACCTGCGACT- $\left.3^{\prime}\right)$ and SLIT3-L (5'-GCAG GTTGGGCAACTTCTTGA- $3^{\prime}$ ) with a SLIT3-specific product size of $85 \mathrm{bp}$, and RPLPO-U (5'-GGCGACCTGGAAGTCCAACT- $\left.3^{\prime}\right)$ and $R P L P O-L$ (5'-CCATCAGCACCACAGCCTTC- $\left.3^{\prime}\right)$ with a RPLPOspecific product size of $149 \mathrm{bp}$. PCR was performed using the SYBR $^{\circledR}$ Green PCR Core Reagents kit (Perkin-Elmer). To avoid amplification of contaminated genomic DNA, one of the two primers was placed at the junction between two exons. The thermal cycling conditions comprised of an initial denaturation step at $95^{\circ} \mathrm{C}$ for $10 \mathrm{~min}$ and $50 \mathrm{cycles}$ of $95^{\circ} \mathrm{C}$ for $15 \mathrm{~s}$ and $65^{\circ} \mathrm{C}$ for $1 \mathrm{~min}$.

\section{Cell lines and 5-aza-2' deoxycytidine treatment}

Breast, colorectal and glioma tumour cell lines were routinely maintained in RPMI 1640 (Invitrogen, San Diego, CA, USA) supplemented with $10 \%$ FCS at $37^{\circ} \mathrm{C}, 5 \% \mathrm{CO}_{2} .5-10 \times 10^{5}$ cells were plated and allowed $24 \mathrm{~h}$ growth before addition of 5 -aza- $2^{\prime}$ deoxycytidine (Sigma). The medium was changed $24 \mathrm{~h}$ after treatment and then every 3 days. RNA was prepared at 5 and 7 days after treatment using the Rneasy kit (Qiagen) according to manufacturers' instructions.

\section{Expression analysis}

Breast, colorectal and glioma cell line were treated with $5 \mu \mathrm{M}$ demethylating agent 5 -aza- $2^{\prime}$-deoxycytidine freshly prepared in $\mathrm{ddH}_{2} \mathrm{O}$ and filter-sterilised. Extracted RNA $(1 \mu \mathrm{g})$ was used as a template for cDNA synthesis using SuperScript ${ }^{\mathrm{TM}}$ III RNase $\mathrm{H}^{-}$ Reverse Transcriptase (Invitrogen - according to the manufacturers' instructions). In total, $2 \mu \mathrm{l}(10 \%)$ of the first strand reaction was used for PCR (Invitrogen - according to the manufacturers' instructions). Primers used for SLIT1, SLIT3 and GAPDH RT - PCR are described in Table 1. The PCR theromocycle (Hybaid) consisted of an initial denaturation of $10 \mathrm{~min}$ at $95^{\circ} \mathrm{C}$ followed by 35 cycles of $95^{\circ} \mathrm{C}$ for $30 \mathrm{~s}$, annealing temperature for $30 \mathrm{~s}, 72^{\circ} \mathrm{C}$ for $30 \mathrm{~s}$ and a final extension of $5 \mathrm{~min}$ at $72^{\circ} \mathrm{C}$. PCR products were visualised on a $2 \%$ agarose gel with added ethidium bromide.

\section{RESULTS}

\section{SLIT1 and SLIT3 expression analysis in normal tissues using quantitative real-time RT - PCR}

We investigated the expression pattern of SLIT1 and SLIT3 genes in a wide range of normal human tissues using quantitative realtime RT - PCR (see Materials and Methods). SLIT3 was expressed in majority of tissues analysed, with the highest expression in skin, brain cerebellum and lung and lowest expression in fetal liver, 
A

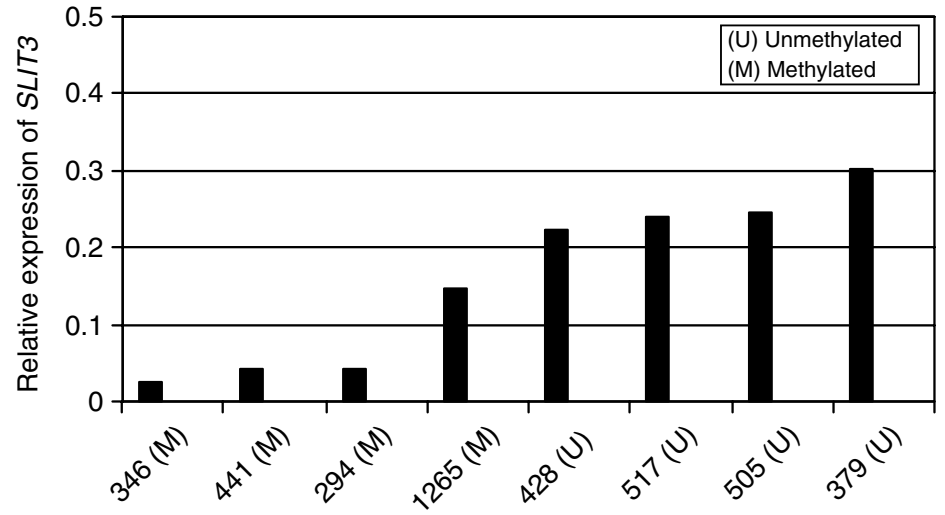

Primary breast tumour sample

B

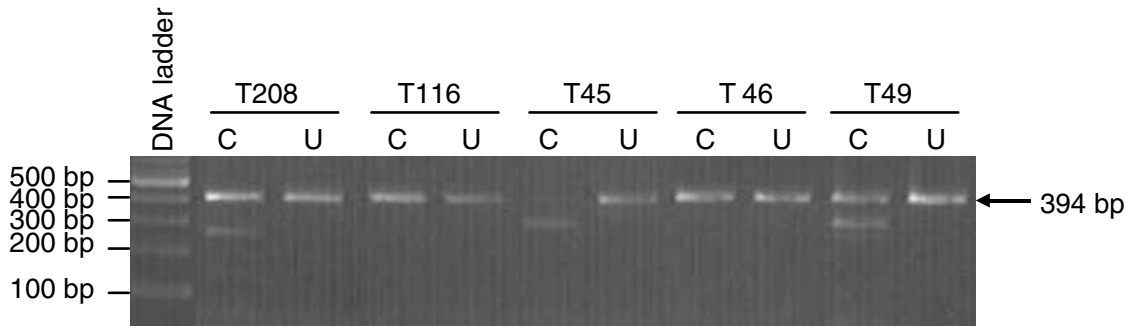

C

CpGs $1 \underline{2} \underline{3} 4 \underline{5} \underline{6} \underline{7} \underline{8} \underline{9} 10111213 \underline{1415} 16 \underline{17} 1819 \underline{20} \underline{21} 2223242526272829 \underline{30}$

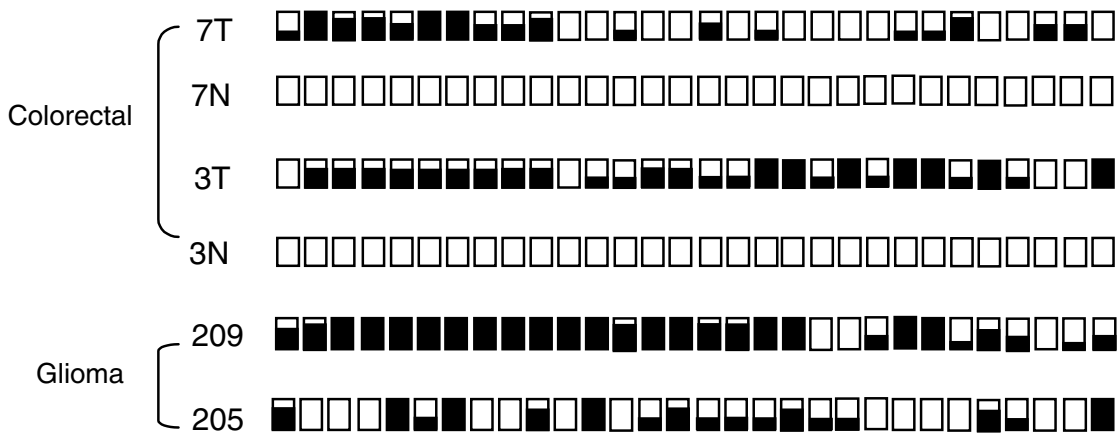

Figure 4 (A) Relative expression of SLIT3 gene in methylated $(M)$ and unmethylated $(U)$ breast tumours using real-time RT-PCR as described in Materials and Methods (B) BstUI digest of SLIT3 CpG island COBRA PCR products from glioma (T208, TI I6, T45) and colorectal (T46, T49) primary tumours. (C) COBRA PCR products from glioma and colorectal primary tumours were cloned and sequenced. For each tumour, several clones were sequenced and the methylation status for the first $30 \mathrm{CpGs}$ is shown. White and black squares represent unmethylated and methylated CpGs, resepectively. Partially filled squares represent partially methylated CpGs. 7T and 3T represent colorectal tumours, $7 \mathrm{~N}$ and $3 \mathrm{~N}$ represent corresponding normal colon samples. 209T and 205T represent glioma tumours.

bone marrow and stomach. While, SLIT1 expression was much more restricted (brain and nervous system) (Figure 1).

\section{Epigenetic inactivation of the SLIT3 gene in tumour cell lines}

The SLIT3 putative promoter region was predicted by Promoter Inspector software (http://www.genomatrix.de). This region is from -576 to +9 relative to the translation start site. This region fulfilled the criteria of a $\mathrm{CpG}$ island with a GC content of $77 \%$ and an observed:expected $\mathrm{CpG}$ ratio of 0.86 (CpG plot programme at http://www.ebi.ac.uk/Tools/). We investigated the methylation status of this $5^{\prime} \mathrm{CpG}$ island associated with the SLIT3 gene in various human tumour cell lines. For this analysis, we utilised the COBRA assay on bisulphite-modified DNA. Figure 2A shows the sequence of the region analysed and the primers used (sequence shown is reverse strand bisulphite modified and all CG methylated), TaqI and BstUI sites are underlined. This CpG island was found to be hypermethylated in 12 out of $29(41 \%)$ breast, one out of three (33\%) NSCLC, zero out of 12 (0\%) SCLC, two out of six (33.3) colorectal and in two out of seven (29\%) glioma tumour cell lines. The COBRA PCR products were cloned and several clones of each tumour cell line were sequenced to determine the pattern and extent of methylation. As seen in Figure 3A, majority of the $30 \mathrm{CG}$ dinucleotides were hypermethylated for MCF-7, HCC712 and HCC38 (breast tumour lines) and SW48 (colorectal tumour line), while breast tumour cell line HCC70 was unmethylated. SLIT3 expression was restored in tumour lines that were heavily methylated (MCF-7 and SW48) by treating the cell lines with 5aza-2-deocycytidine (Figure 3B), while the unmethylated glioma tumour cell line T17 did not show any change in expression. 


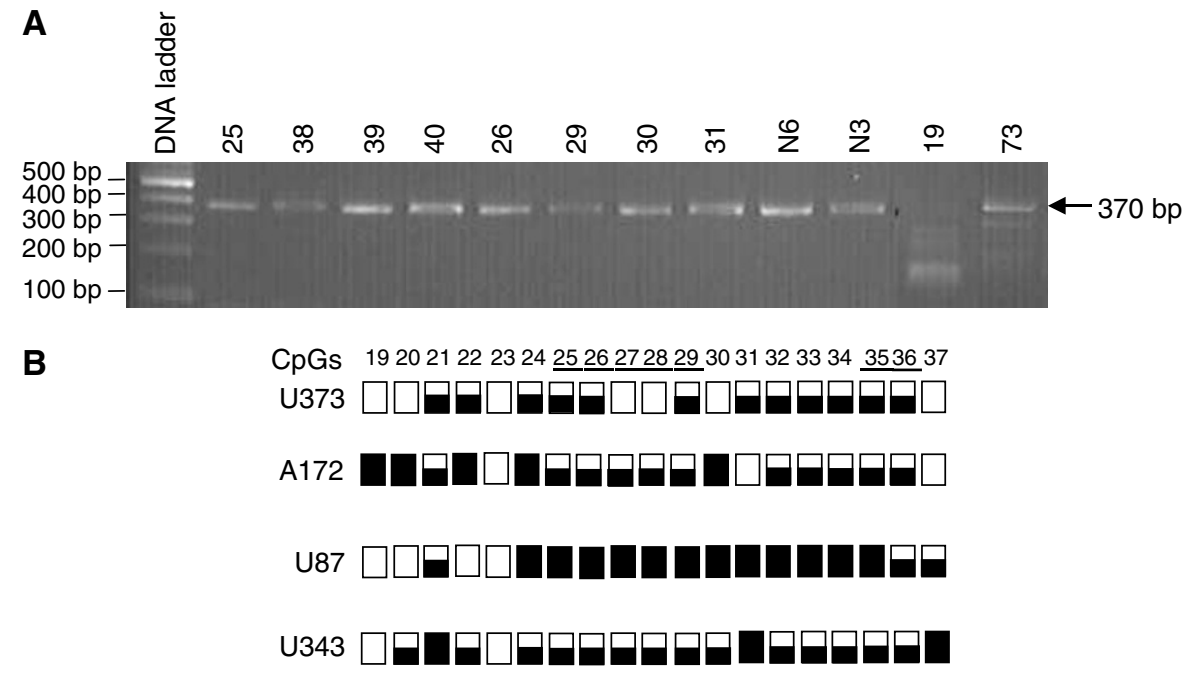

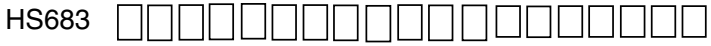
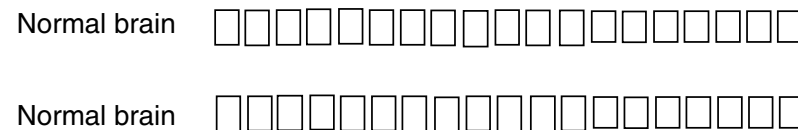

C

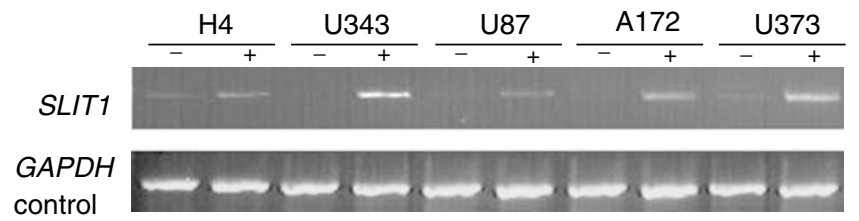

Figure 5 (A) BstUI digest of SLITI COBRA PCR products from glioma grade IV tumours and normal brain (N6 and N3) which were included as negative controls for methylation. Tumours 19 and 73 show digestion with BstUI. (B) SLITI COBRA PCR products were directly sequenced from glioma tumour cel lines and normal brain. The methylation status from CpG 19-37 is shown. White and black squares represent unmethylated and methylated CpGs, respectively. Partially filled squares represent partially methylated CpGs. Glioma tumour cell line Hs683 is unmethylated for SLITI (C) Expression of SLITI in glioma tumour cell lines before and after treatment with 5-aza-2'-deoxycytidine. GAPDH was used as positive control to ensure RNA integrity and equal loading.

\section{Epigenetic inactivation of the SLIT3 gene in primary tumours}

We then analysed the methylation status of the above CpG island in primary tumours using COBRA analysis followed by sequencing of the cloned PCR products. Five out of $32(16 \%)$ breast tumours were found to be methylated for SLIT3. Using real-time RT-PCR, we demonstrated that the SLIT3 methylation in breast tumours correlated with reduced SLIT3 expression as compared to unmethylated breast tumours (Figure 4A). SLIT3 $5^{\prime}$ CpG island was also hypermethylated in 12 out of 32 (37.5\%) colorectal tumours and in 21 out of 60 (35\%) glioma primary tumours. Since the tumour samples used in this study were not microdissected, in majority of the primary tumors unmethylated bands were also detected. No methylation was found in corresponding normal tissues from the colorectal or glioma patients or in the DNA isolated from normal brains. Similar to the tumour cell line data, sequencing of cloned PCR products confirmed that majority of the 30 CG dinculeotides analysed were methylated in primary tumours (Figure 4B, C).

\section{Epigenetic inactivation of SLIT1 gene in gliomas}

The SLIT1 CpG island was predicted to be from -574 to +192 and had a GC content of $71 \%$ and had an observed : expected CpG ratio of 0.81 (CpG plot programme at http://www.ebi.ac.uk/Tools/). This region overlapped with the SLIT1 putative promoter region predicted by Promoter Inspector software (http://www.genomatrix.de). Since SLIT1 expression is neuronal specific, we analysed the methylation status of the $5^{\prime} \mathrm{CpG}$ island of the SLIT1 gene in glioma tumour cell lines and primary tumours by COBRA and direct sequencing of bisulphite-modified DNA (Figure 2B). Five out of six $(83 \%)$ glioma tumour lines were methylated, while only two of $20(10 \%)$ glioma tumours demonstrated SLIT1 methylation (Figure 5A, B). No methylation was found in DNA isolated from normal brains. SLIT1 expression was restored/upregulated in five glioma tumour lines (methylated for SLIT1) by treatment with 5aza-2'-deoxycytidine (Figure 5C).

\section{DISCUSSION}

The Slit genes encode ligands for the roundabout (robo) receptors. The Slit-Robo interactions mediate the repulsive cues on axons and growth cones during neural development. The Slit family comprises of large extracellular matrix-secreted and membraneassociated glycoproteins with multiple functional domains (reviewed in Brose and Tessier-Lavigne, 2000). Slit genes have been identified in Drosophila, Caenorhabditis elegans, Xenopus, chickens, mice, rats and humans. There are three known mammalian 
SLIT genes (SLIT1, SLIT2, SLIT3) located on chromosome $10 \mathrm{q} 23.3-\mathrm{q} 24,4 \mathrm{p} 15.2$ and $5 \mathrm{q} 35-\mathrm{q} 34$, respectively. slit2 and slit3 genes are expressed in neuronal as well as nonneuronal tissues, while slit1 expression is specific to the brain (Wu et al, 2001 and this report). Slit2 homozygous deficiency in mice is lethal, while Slit1 and Slit3 homozygous mice are viable (Plump et al, 2002; Yuan et al., 2003).

In our earlier studies, we demonstrated that the ligand (SLIT2) for robo1 receptor was frequently methylated in lung, breast, colorectal and glioma tumours and that the methylation correlated with loss of SLIT2 expression. More recently, we demonstrated SLIT2 methylation in neuroblastoma, Wilms' tumour and renal cell carcinoma (Astuti et al, 2004). Furthermore, in in vitro assays, SLIT2 suppressed tumour growth (Dallol et al, 2002a, 2003a, b).

SLIT3 is located at $5 \mathrm{q} 35-\mathrm{q} 34$, which is a frequent region of allelic loss in colorectal and lung cancers (Girard et al, 2000; Goel et al, 2003). We have now demonstrated that SLIT3 $5^{\prime}$ CpG island similar to SLIT2 is frequently hypermethylated in colorectal and glioma tumours and less so in breast tumours. And loss of SLIT3 expression can be reversed by treatment with a demethylating

\section{REFERENCES}

Agathanggelou A, Honorio S, Macartney DP, Martinez A, Dallol A, Rader J, Fullwood P, Chauhan A, Walker R, Shaw JA, Hosoe S, Lerman MI, Minna JD, Maher ER, Latif F (2001) Methylation associated inactivation of RASSF1A from region $3 \mathrm{p} 21.3$ in lung, breast and ovarian tumours. Oncogene 20: $1509-1518$

Astuti D, Da Silva NF, Dallol A, Gentle D, Martinsson T, Kogner P, Grundy R, Kishida T, Yao M, Latif F, Maher ER (2004) SLIT2 promoter methylation analysis in neuroblastoma, Wilms' tumour and renal cell carcinoma. Br J Cancer 90: 515-521

Brose K, Bland KS, Wang KH, Arnott D, Henzel W, Goodman CS, TessierLavigne M, Kidd T (1999) Slit proteins bind Robo receptors and have an evolutionarily conserved role in repulsive axon guidance. Cell 96: 795-806

Brose K, Tessier-Lavigne M (2000) Slit proteins: key regulators of axon guidance, axonal branching, and cell migration. Curr Opin Neurobiol 10: 95-102

Burbee DG, Forgacs E, Zöchbauer-Müller S, Shivakumar L, Gao B, Randle D, Virmani A, Bader S, Sekido Y, Latif F, Fong K, Gazdar AF, Lerman MI, White M, Minna JD (2001) Epigenetic inactivation of RASSF1A in lung and breast cancers and malignant phenotype suppression. J Natl Cancer Inst 93: $691-699$

Dallol A, Da Silva NF, Viacava P, Minna JD, Maher ER, Latif F (2002a) SLIT2, a human homologue of the Drosophila Slit2 gene, has tumor suppressor activity and is frequently inactivated in lung and breast cancers. Cancer Res 62: 5874-5880

Dallol A, Forgacs E, Martinez A, Sekido Y, Walker R, Kishida T, Rabbitts P, Maher ER, Latif F (2002b) Tumour specific promoter region methylation of the human homologue of the Drosophila Roundabout gene DUTT1 (ROBO1) in human cancers. Oncogene 21: 3020-3028

Dallol A, Krex D, Hesson L, Eng C, Maher ER, Latif F (2003a) Frequent epigenetic inactivation of the SLIT2 gene in gliomas. Oncogene 22: $4611-4616$

Dallol A, Morton D, Maher ER, Latif F (2003b) SLIT2 axon guidance molecule is frequently inactivated in colorectal cancer and suppresses growth of colorectal carcinoma cells. Cancer Res 63: 1054-1058

Dammann R, Li C, Yoon JH, Chin PL, Bates S, Pfeifer GP (2000) Epigenetic inactivation of a RAS association domain family protein from the lung tumour suppressor locus 3p21.3. Nat Genet 25: 315-319

Dammann R, Schagdarsurengin U, Strunnikova M, Rastetter M, Seidel C, Liu L, Tommasi S, Pfeifer GP (2003) Epigenetic inactivation of the Rasassociation domain family 1 (RASSF1A) gene and its function in human carcinogenesis. Histol Histopathol 18: 665-677

Girard L, Zochbauer-Muller S, Virmani AK, Gazdar AF, Minna JD (2000) Genome-wide allelotyping of lung cancer identifies new regions of allelic loss, differences between small cell lung cancer and non-small cell lung cancer, and loci clustering. Cancer Res 60: 4894-4906

Goel A, Arnold CN, Niedzwiecki D, Chang DK, Ricciardiello L, Carethers JM, Dowell JM, Wasserman L, Compton C, Mayer RJ, Bertagnolli MM, agent. While SLIT1 gene is frequently methylated in glioma tumour lines but at low frequencies in glioma tumours, hence SLIT1 may play a role in late gliomagenesis.

Slits, netrins, semaphorins and the ephrins constitute conserved families of axonal guidance cues that have prominent developmental effects. Recently, SEMA3B was also demonstrated to be inactivated in lung cancer by promoter region hypermethylation (Tomizawa et al, 2001; Kuroki et al, 2003). Re-expression of SEMA3B inhibited lung cancer cell growth and induced apoptosis.

The finding of epigenetic inactivation in various human cancers of ROBO1, SEMA3B, SLIT2 and now SLIT3 and to a lesser extent SLIT1, all of which are involved in axon and cell migration in Drosophila and vertebrates, suggests a novel, and common underlying theme for these molecules in tumour suppression.

\section{ACKNOWLEDGEMENTS}

This work was in part supported by Breast Cancer Campaign and Cancer Research UK.
Boland CR (2003) Characterization of sporadic colon cancer by patterns of genomic instability. Cancer Res 63: $1608-1614$

Herman JG, Baylin SB (2003) Gene silencing in cancer in association with promoter hypermethylation. N Engl J Med 349: 2042 - 2054

Huminiecki L, Gorn M, Suchting S, Poulsom R, Bicknell R (2002) Magic roundabout is a new member of the roundabout receptor family that is endothelial specific and expressed at sites of active angiogenesis. Genomics 79: $547-552$

Jones PA, Baylin SB (2002) The fundamental role of epigenetic events in cancer. Nat Rev Genet 3: 415-428

Kidd T, Bland KS, Goodman CS (1999) Slit is the midline repellent for the robo receptor in Drosophila. Cell 96: 785-794

Kidd T, Brose K, Mitchell KJ, Fetter RD, Tessier-Lavigne M, Goodman CS, Tear G (1998) Roundabout controls axon crossing of the CNS midline and defines a novel subfamily of evolutionarily conserved guidance receptors. Cell 92: $205-215$

Kuroki T, Trapasso F, Yendamuri S, Matsuyama A, Alder H, Williams NN, Kaiser LR, Croce CM (2003) Allelic loss on chromosome 3p21.3 and promoter hypermethylation of Semaphorin $3 B$ in non-small cell lung cancer. Cancer Res 63: 3352-3355

Lerman MI, Minna JD (2000) The 630-kb lung cancer homozygous deletion region on human chromosome 3 p21.3: identification and evaluation of the resident candidate tumor suppressor genes. The International Lung Cancer Chromosome 3p21.3 Tumor Suppressor Gene Consortium. Cancer Res 60: 6116-6133

Li HS, Chen JH, Wu W, Fagaly T, Zhou L, Yuan W, Dupuis S, Jiang ZH, Nash W, Gick C, Ornitz DM, Wu JY, Rao Y (1999) Vertebrate slit, a secreted ligand for the transmembrane protein roundabout, is a repellent for olfactory bulb axons. Cell 96: $807-818$

Pfeifer GP, Yoon JH, Liu L, Tommasi S, Wilczynski SP, Dammann R (2002) Methylation of the RASSF1A gene in human cancers. Biol Chem 383: 907-914

Plump AS, Erskine L, Sabatier C, Brose K, Epstein CJ, Goodman CS, Mason CA, Tessier-Lavigne M (2002) Slit1 and Slit2 cooperate to prevent premature midline crossing of retinal axons in the mouse visual system. Neuron 33: $219-232$

Sundaresan V, Chung G, Heppell-Parton A, Xiong J, Grundy C, Roberts I, James L, Cahn A, Bench A, Douglas J, Minna J, Sekido Y, Lerman M, Latif F, Bergh J, Li H, Lowe N, Ogilvie D, Rabbitts P (1998) Homozygous deletions at 3 p12 in breast and lung cancer. Oncogene 17: $1723-1729$

Tomizawa Y, Sekido Y, Kondo M, Gao B, Yokota J, Roche J, Drabkin H, Lerman MI, Gazdar AF, Minna JD (2001) Inhibition of lung cancer cell growth and induction of apoptosis after reexpression of 3 p21.3 candidate tumor suppressor gene SEMA3B. Proc Natl Acad Sci USA 98: $13954-13959$ 
Epigenetic inactivation of SLIT3 and SLITI genes in human cancers RE Dickinson et al

Wong K, Park HT, Wu JY, Rao Y (2002) Slit proteins: molecular guidance cues for cells ranging from neurons to leukocytes. Curr Opin Genet Dev 12: $583-591$

Wu JY, Feng L, Park HT, Havlioglu N, Wen L, Tang H, Bacon KB, Jiang Zh, Zhang Xc, Rao Y (2001) The neuronal repellent Slit inhibits leukocyte chemotaxis induced by chemotactic factors. Nature 410: $948-952$

Xian J, Clark KJ, Fordham R, Pannell R, Rabbitts TH, Rabbitts PH (2001) Inadequate lung development and bronchial hyperplasia in mice with a targeted deletion in the Dutt1/Robo1 gene. Proc Natl Acad Sci USA 98: $15062-15066$

Yuan SS, Cox LA, Dasika GK, Lee EY (1999) Cloning and functional studies of a novel gene aberrantly expressed in RB-deficient embryos. Dev Biol 207: $62-75$

Yuan W, Rao Y, Babiuk RP, Greer JJ, Wu JY, Ornitz DM (2003) A genetic model for a central (septum transversum) congenital diaphragmatic hernia in mice lacking Slit3. Proc Natl Acad Sci USA 100: 5217-5222 